\title{
Potential adoption and management of insect-resistant potato in Peru, and implications for genetically engineered potato
}

\author{
Jasper BUIJS*, Marianne MARTINET, Felipe de MENDIBURU, Marc GHISLAIN \\ International Potato Center (CIP), Apartado 1558, Lima 12, Peru
}

This paper analyzes some important issues surrounding possible deployment of genetically engineered (GE) insect-resistant potato in Peru, based on a large farmer survey held in Peru in 2003. We found that the formal seed system plays a limited role compared with the informal seed system, especially for smallholder farmers. Although $97 \%$ of smallholder farmers would buy seed of an insect-resistant variety, a majority would buy it only once every 2 to 4 years. Survey data show that farmers would be willing to pay a premium of $50 \%$ on seed cost for insect resistant varieties. Paying price premiums of $25 \%$ to $50 \%$, farmers would still increase their net income, assuming insect resistance is high and pesticide use will be strongly reduced. Of all farmers, $55 \%$ indicated preference for insect-resistant potato in varieties other than their current varieties. The survey indicates that smallholder farmers are interested to experiment with new varieties and have a positive perception of improved varieties. Based on these findings, and considering the difficulties implementing existing biosafety regulatory systems such as those in place in the U.S. and E.U., we propose to develop a variety-based segregation system to separate GE from conventionally bred potatoes. In such a system, which would embrace the spread of GE potatoes through informal seed systems, only a limited number of sterile varieties would be introduced that are easily distinguishable from conventional varieties.

Keywords: genetically engineered crops / potato / segregation / variety / costs and benefits / developing countries

\section{INTRODUCTION}

Agriculture in many developing countries is still the most important economic sector, with the largest part of their population living off agricultural production. Large numbers of these farmers are smallholders. Harsh climatic conditions, marginal and isolated areas, subsistencefarming at family and community level, and much more diversity in pests and pathogens contrast developing versus developed country agriculture.

Potato production in the Andes is affected by a particularly high number of pests and diseases, resulting in low yields or extensive use (often sub-optimal) of pesticides (Cole et al., 1998). Yield improvements, production cost reductions, and reduced negative health and environmental impacts have been observed for other crops when pest and disease resistant varieties were obtained from applying genetic engineering (GE) (Pray et al., 2002; Qaim and Zilberman, 2003). This may apply as well to adoption of GE insect-resistant potato and provide such benefits for farmers, environment, and consumers in developing countries (Ghislain et al., 1999).

Peru is host to almost 100 wild potato species (Salas et al., 2001; Spooner et al., 1999), and most of the thousands of landraces, or farmer varieties, occur in Peru and Bolivia (Huamán, 1998). Of the approximately 40 improved potato varieties developed by national and regional breeding programs, only a few are available country-wide.

Peru counts about 600000 potato farmers (III Censo Nacional Agropecuario, Ministerio de Agricultura, Peru; Lima, 1996). Most of Peru's potato cultivation is done in the highlands (approximately $90 \%$ ) and about $10 \%$ is done in the coastal areas. Most of the native cultivars are grown in the highlands in the South and the North of the country. Highland farmers balance their potato production between native cultivars and improved varieties based on the varieties' differences in productivity versus market

\footnotetext{
* Corresponding author: jasper_buijs25@yahoo.com
} 
prices, on avoiding risk, and on a range of cultural factors.

There are two different seed systems. The so-called informal seed system refers to smallholder farmers who produce their own seed, exchange, or buy seed from other farmers. The formal seed system is specialized in commercial potato production and involves a certification process (Thiele, 1998).

Peru currently has started to develop its own biosafety regulations and is gradually developing its regulatory capacity. However, there is in general little scientific capacity for biotechnological research and development available in the country (Falconi, 1996). The general objective of the government's agricultural policy is to increase the national producers' efficacy, profitability, and competitiveness, and a major objective is increasing exports (Falconi, 1996).

The two best-known genetically engineered (GE) crop regulation systems are those developed and currently in use in the U.S. and the E.U. These regulatory frameworks reflect two contrasting and opposed views on how GE crops and their derived products should be regulated.

The US's equivalence-based regulatory framework relies on existing health and safety regulations for other adapted and modified products to assess the products derived from genetic engineering. In this system, existing regulations are adjusted to suit the regulatory requirements that new products bring. This process of updating regulation is dynamic and continues to take place with the advance of our scientific knowledge (Weiss, 2000). Segregation and labeling of GE (containing) products is only required if there are health concerns with the product, differences in use or nutritional value, or when the common name no longer adequately describes the food derived from the GE crop plant. The market-driven traditions in the United States are conducive to a situation in which GE and non-GE products should have equal economic opportunity.

The European Union has adopted a new and unique regulatory framework. This framework is based on strict segregation and labeling, and it requires four things in addition to the requirements of the US regulatory framework. (1) The public is informed about GE food products through a mandatory labeling system. (2) A postmarket monitoring system exists that includes research into the long-term effects of GE-derived products on human health and the environment. (3) Traceability is to be ensured throughout the entire production and distribution process. (4) Co-existence between GE and organic farming is meant to provide farmers and consumers equal opportunity for choice.
Existing biosafety regulatory systems, like those in place in the US and EU, are difficult to transpose to developing countries, mainly because of the importance of informal seed systems and small-scale agriculture. Both regulatory systems therefore pose serious constraints regarding adoption or deployment in such countries. Although the non-requirement for labeling seems an economically attractive option at first sight, in adopting the equivalence-based US regulatory system, developing countries cannot count on extensive experience in safe handling of products and in enforcement, such as are available in the US. Any requirements for regulation for internal or export markets would be hard to meet for the vast majority of developing countries. The EU biosafety regulatory system, based on strict segregation, traceability, and mandatory labeling along the whole food chain from seed to food, likely requires considerable scientific and institutional capacity that is rarely available in developing countries. The difficulties associated with prevailing informal seed systems (farmer-to-farmer seed trade is vitally important for smallholder farmers) and the large number of smallholder farmers in developing countries would make the tracing and labeling process relatively more costly and difficult to implement. Such costs induced by GE innovations may outweigh the gains (Lapan and Moschini, 2004). The inability to implement an effective segregation system has generated the fear of export loss for agricultural products in developing countries (Cohen and Paarlberg, 2002). Together, these factors caused many developing countries to decide not to grow GE crops yet. Therefore, it seems that neither the US nor the EU regulatory system is appropriate for developing countries.

Instead, a regulatory system could be developed locally as proposed by McLean et al. (2002). Although more time-consuming, this conceptual framework approach for biosafety regulation development presents the advantages of using local capacity and context as the basis.

The present research looks at the implications of the introduction of GE potato varieties with insect resistance $(B t)$, taking Peru as a case that presents many of the complexities for deployment of GE potato varieties in developing countries, as described in Ghislain et al. (2003). The safety of $B t$ as bio-pesticide has a long history of safe use, whereas its expression in plants has already a decade of use with no reports of adverse effects on human health (Betz et al., 2000; Kough, 2003; Shelton et al., 2002). An extensive farmer survey forms the basis of our assessment of needs and opportunities for deployment of GE potatoes in the Andean region, and in particular current potato cultivation constraints, insect control 
methods and their associated costs, aspects of potato variety choice, and farmers' perception of the importance of advantages and disadvantages associated with the introduction of insect-resistant (GE) potato. The survey intentionally avoided making reference to GE varieties due to the complexity of presenting a balanced view on the technology that is currently negatively advertised locally.

\section{RESULTS}

\section{Potato production problems in Peru}

The farmer survey on potato variety use, management of insect pests and diseases, and farmers' views on the adoption of new varieties revealed which are the most important potato cultivation constraints among Peruvian smallholder potato farmers. Among different abiotic cultivation constraints examined, frost appeared to be the biggest abiotic constraint to potato cultivation, followed immediately by drought, based on the relative incidence index ${ }^{1}$ calculated by the number of times this production constraint was reported as most important by the farmers in the survey (Tab. 1). However, considering the extent of the damages to crop cultivation (for every four cases of little damage, one case of total destruction of the crop occurs), frost is more damaging than drought (for every sixteen cases of little damage, one case of total destruction occurs). Flooding occurs much less frequently, but has a very high relative damage index.

When all potato cultivation constraints are assessed, which include abiotic and biotic factors and marketing and price problems, potato late blight has the highest importance, followed by the insect pests Andean potato weevil (APW) and potato tuber moth (PTM) (Tab. 2). However, by summing the incidence indices of these two insect problems, the total insect problem appeared to be the most important potato production constraint, followed closely by the late blight disease.

\section{Variety choice}

Survey data about variety choice indicated the farmers' most popular current varieties (Tab. 3). The best-appreciated characteristics in these varieties are productivity and market price, followed by disease resistance and taste. Earliness is also an important characteristic.

Table 1. Abiotic factors as potato cultivation constraints: relative incidence index and relative damage index. Values in parenthesis are the limits of the confidence interval at $95 \%$.

\begin{tabular}{lccccc}
\hline \hline Damage type & Relative incidence index & \multicolumn{2}{c}{ Relative damage index } \\
& & Little & Medium & Much & Complete \\
\hline Frost & $3.0(2.75-3.15)$ & 4.0 & 4.0 & 2.1 & 1.0 \\
Drought & $3.0(2.75-3.15)$ & 16.0 & 17.4 & 7.5 & 1.0 \\
Hail & $2.9(2.71-3.11)$ & 6.0 & 6.5 & 2.3 & 1.0 \\
Flooding & $1.0(0.80-1.15)$ & 1.5 & 2.1 & 1.1 & 1.0 \\
\hline
\end{tabular}

Table 2. Potato production constraints: relative incidence index, $\%$ of Peruvian farmers (based on sample) who experience the constraint as the primary problem. Values in parenthesis are the limits of the confidence interval at $95 \%$.

\begin{tabular}{lcc}
\hline \hline Damage type & Relative incidence index & \% of Peruvian farmers, based on sample \\
\hline Late blight & $32.8(28.05-37.91)$ & $26.2 \%$ \\
Andean potato weevil & $21.5(17.57-26.08)$ & $17.2 \%$ \\
Potato tuber moth & $13.0(9.91-16.87)$ & $10.4 \%$ \\
Low market price & $7.8(5.40-10.98)$ & $6.2 \%$ \\
Frost & $2.5(1.27-4.71)$ & $2.0 \%$ \\
Low productivity & $1.3(0.46-1.07)$ & $1.0 \%$ \\
Drought & $1.0(0.32-2.72)$ & $0.8 \%$ \\
\hline
\end{tabular}

\footnotetext{
${ }^{1}$ The indices indicate how many times more important is one item relative to the other items, as it sets the lowest reported number as one and represents the higher reported numbers as multiplications.
} 
J. Buijs et al.

Table 3. Currently most cultivated potato varieties; relative importance index; advantages and disadvantages.

\begin{tabular}{|c|c|c|c|c|c|c|c|c|c|c|c|c|c|c|}
\hline \multirow[b]{3}{*}{ Canchan } & \multirow{3}{*}{$\begin{array}{c}\begin{array}{c}\text { Rel. imp. } \\
\text { index }\end{array} \\
7.3\end{array}$} & \multicolumn{6}{|c|}{ Advantages ${ }^{1}$} & \multicolumn{7}{|c|}{ Disadvantages $^{1}$} \\
\hline & & \multicolumn{6}{|c|}{ CQ E GMP HP MS NT RB RD ROD } & \multicolumn{7}{|c|}{ GT LP MF MPF NE SB SD SI SOD SS } \\
\hline & & * & * & * & & & & & & * & $*$ & & $*$ & \\
\hline Yungay & 6.4 & & $*$ & $*$ & & * & $*$ & $*$ & * & & & & & \\
\hline Amarilis & 3.6 & & $*$ & $*$ & & & & $*$ & & & & & & $*$ \\
\hline Perricholi & 2.7 & & $*$ & $*$ & & & & & & $*$ & & $*$ & $*$ & \\
\hline Amarilla & 2.0 & & $*$ & & & & & & & & & $*$ & $*$ & \\
\hline Cica & 1.8 & & $*$ & $*$ & $*$ & $*$ & & & & * & & & $*$ & \\
\hline Huayro & 1.6 & $*$ & $*$ & & & $*$ & & & & & & $*$ & $*$ & $*$ \\
\hline Liberteña & 1.3 & & & & & $*$ & $*$ & & & & & & & \\
\hline Q'ompis & 1.2 & * & & & & $*$ & & $*$ & & & & & & $*$ \\
\hline Peruanita & 1.0 & & $*$ & & & $*$ & & $*$ & $*$ & & & & & \\
\hline
\end{tabular}

Table 4. Most sought after potato varieties for future cultivation; relative importance index; advantages.

\begin{tabular}{|c|c|c|c|c|c|c|c|c|}
\hline Future & Rel. imp. & & & $\overline{\mathrm{Ad}}$ & ant: & es & & \\
\hline & & $E$ & $\overline{\mathrm{GMH}}$ & $\mathrm{HD}$ & $\mathrm{HF}$ & NT & $\overline{\mathrm{RB}}$ & OD \\
\hline Unica & 5.5 & $*$ & $*$ & $*$ & $*$ & & $*$ & $*$ \\
\hline Canchan & 4.9 & $*$ & & & $*$ & & & \\
\hline Peruanita & 3.8 & & $*$ & & $*$ & $*$ & & \\
\hline Amarilis & 3.1 & $*$ & & & $*$ & $*$ & & \\
\hline Capiro & 3.0 & & $*$ & & $*$ & & $*$ & \\
\hline Andina & 2.6 & $*$ & $*$ & & $*$ & $*$ & $*$ & \\
\hline Perricholi & 1.6 & - & & & & & & \\
\hline Chazca & 1.3 & - & & & & & & \\
\hline Amarilla & 1.1 & & $*$ & & & $*$ & $*$ & \\
\hline Revolución & 1.1 & $*$ & & & & & & \\
\hline Sureña & 1.0 & & & & $*$ & & & \\
\hline
\end{tabular}

${ }^{1} \mathrm{CQ}=$ good cooking qualities, E=earliness, GMP=good market price, $\mathrm{GT}=$ greening tubers, $\mathrm{HDM}=$ high dry matter, $\mathrm{HP}=$ high productivity, $\mathrm{LP}=$ low productivity, $\mathrm{MF}=$ much fertilizer, $\mathrm{MPF}=$ much price fluctuation, $\mathrm{MS}=$ multiple season use, $\mathrm{NE}=$ no earliness, $\mathrm{NT}=$ nice taste, $\mathrm{RB}=$ resistant blight, $\mathrm{RD}=$ resistant to drought, $\mathrm{ROD}=$ resistant to other diseases, $\mathrm{SB}=$ susceptible to blight, $\mathrm{SD}=$ sensitive to drought, $\mathrm{SI}=$ susceptible to insects, $\mathrm{SOD}=$ susceptible to other diseases, $\mathrm{SS}=$ spoils easy in storage. Values are confident, because the margin of error is below 2.5\% (out of the 500 farmers surveyed, 486 answered that they grow at least one of the listed potato varieties $-82.6 \%$ of the total varieties named - while 14 did not provide an answer at all).

Table 4 shows the varieties that are most sought to be cultivated in the near future. These varieties are appreciated for the same characteristics. Interestingly, the currently popular variety Yungay did not end up in the top 15 varieties sought after for future cultivation.

Varieties that have gradually been abandoned in the past ten years include (in decreasing order of importance) Renacimiento, Liberteña, Mariva, Revolución, Huayro,
Tomasa, Amarilla, Yungay, Huancaya, Limeña, Perricholi, and Bole. The most important reasons for leaving these varieties are low productivity, low level of resistance (mostly to late blight), low price, high investment costs and degeneration or greening of seed tubers or seed tuber unavailability.

Farmer types (landless, very small, small, medium, large, and very large) were categorized according to the size of their land holdings in ha. Surprisingly, variety choice seemed to be largely independent of landholding size. The popularity of currently grown varieties and future sought-after varieties for the different farmer categories is shown in Table 5 and Table 6.

When farmers were asked whether they would prefer a new variety with insect resistance to be similar to their current varieties, or different, the answer distribution showed an almost equal number of farmers preferring a different or a resembling variety, with a slight favor for a different variety. The most important reasons for preferring the resembling variety are derived from conservative arguments (in decreasing order of importance): "the current variety has a good market", "it has good field resistance (to other important production constraints)", and "it has a nice color and taste". The reasons for preferring a different variety were mainly (in decreasing order of importance): "expect better resistance", "expect better production", "just to try", and "expect good quality seed (tubers)". These reasons for preferring a different variety indicate a relatively high level of trust in new improved potato varieties, and willingness to experiment with new varieties.

\section{Seed purchase}

Although most farmers that cultivate the currently popular varieties buy seed tubers, most do not obtain these through 
GE potato segregation

Table 5. Current potato varieties' popularity by farmers' land holding size.

\begin{tabular}{lllllll}
\hline \hline Current varieties & \multicolumn{5}{c}{ Farmer type by land area (ha) [number of farmers in the category] } \\
& $0-0.49[11]$ & $0.5-0.99[21]$ & $1-2.99[154]$ & $3-9.99[257]$ & $10-50[53]$ & $>50[4]$ \\
\hline Nr 1 Variety & Canchan & Canchan Yungay & Canchan & Canchan & Canchan & Canchan \\
Nr 2 Variety & Amarilis & Perricholi & Yungay & Yungay & Amarilis & Amarilis Yungay \\
Nr 3 Variety & Cica Yungay & Amarilis & Amarilis & Amarilis & Yungay & Amarilla \\
Nr 4 Variety & Perricholi & Cica & Perricholi & Cica & Perricholi & Peruanita \\
Nr 5 Variety & Q'ompis Machala & Huayro & Amarilla & Amarilla & Amarilla & \\
Nr 6 Variety & & & Cica Huayro & Perricholi & Huayro & \\
Nr 7 Variety & & & Peruanita & Q'ompis & & \\
Nr 8 Variety & & & Huayro Liberteña & & \\
Nr 9 Variety & & & Peruanita & & \\
\hline
\end{tabular}

Table 6. Future potato varieties' popularity by farmers' land holding size.

\begin{tabular}{|c|c|c|c|c|c|c|}
\hline \multirow[t]{2}{*}{ Future varieties } & \multicolumn{6}{|c|}{ Farmer type by land area (ha), same number of farmers in categories as in Table 5} \\
\hline & $0-0.49$ & $0.5-0.99$ & $1-2.99$ & $3-9.99$ & $10-50$ & $>50$ \\
\hline Nr 1 Variety & Canchan & Unica Capiro & Unica & Canchan & Canchan & Capiro \\
\hline $\mathrm{Nr} 2$ Variety & Unica & Revolución & Canchan & Unica Peruanita & Unica Capiro & \\
\hline Nr 3 Variety & Andina Sureña & Andina & Amarilis & Amarilis Capiro & Amarilis Peruanita & \\
\hline $\mathrm{Nr} 4$ Variety & & $\begin{array}{l}\text { Perricholi } \\
\text { Chacacina }\end{array}$ & Amarilla Peruanita & Andina & Perricholi & \\
\hline Nr 5 Variety & & Canchan & $\begin{array}{l}\text { Andina Capiro } \\
\text { Perricholi }\end{array}$ & Perricholi & Andina & \\
\hline Nr 6 Variety & & Peruanita & & Revolución & & \\
\hline $\mathrm{Nr} 7$ Variety & & & & Huayro Chazca & & \\
\hline
\end{tabular}

the formal seed system (certified seed sellers), but rather through self-multiplication after buying the tubers once as a group, from neighbors from their own community or from acquaintances from other communities (Tab. 7). Smallholder farmers do buy seed tubers, but the majority does so only once in two to four years, and maintains their varieties through their own multiplication of planting material.

\section{Management practices}

Since two important issues with the deployment and use of a GE potato with insect resistance are insect resistance management (IRM) and establishment of segregation between GE and conventional varieties, two other questions were raised: 1) whether farmers would be able to always sow the new insect-resistant variety next to one of their current susceptible varieties, and 2) whether farmers would be able to refrain from mixing varieties during sowing, harvest, and storage. Of all farmers, $68 \%$ stated they would not be able to always sow the insectresistant variety next to one of their current susceptible varieties $^{2}$. Regarding seed separation practices, $89 \%$ of the farmers stated they could refrain from mixing (many farmers already prefer not to mix varieties) and $11 \%$ stated they could not refrain from mixing varieties.

Another aspect related to segregation of potato varieties is the flow of potato varieties through the markets. It can be argued that markets supplied by higher numbers of farmers with higher numbers of different potato varieties would in principle be markets that could also contribute more strongly to possible occurrence of seed mixes of GE and conventional varieties (e.g., a smallholder farmer who mixes his varieties could buy a

\footnotetext{
${ }^{2}$ Farmers were explained during the interviews that in order to sow this new, insect-resistant variety, they would be obliged to also sow a variety that is not insect-resistant (a refuge), to control build up of resistance within the insect.
} 
Table 7. Some of the most popular varieties; percentages of mode of seed tuber purchase; percentages of agents from whom the seed tubers were obtained.

\begin{tabular}{|c|c|c|c|c|c|c|c|c|c|c|}
\hline \multirow[t]{2}{*}{ Variety } & \multicolumn{3}{|c|}{ Ratios how obtained ${ }^{1}$} & \multicolumn{7}{|c|}{ Ratios obtained from ${ }^{2}$} \\
\hline & B & Bw & $\mathbf{T}$ & $\mathbf{O}$ & AOC & : $\mathbf{N}$ & : $\mathbf{M}$ & $\mathbf{F}$ & NGO & CS \\
\hline Canchan & 91.7 & 3.3 & 5.0 & 39.6 & 24.7 & 18.7 & 8.9 & 5.1 & - & 3.0 \\
\hline Yungay & 80.6 & 13.9 & 5.5 & 72.6 & 16.2 & 2.6 & 4.3 & - & 3.4 & 0.9 \\
\hline Amarilis & 78.4 & 16.2 & 5.4 & 42.1 & - & 21.0 & 21.0 & 8.8 & 5.3 & 1.8 \\
\hline Perricholi & 80.0 & 20.0 & - & 81.0 & 9.5 & 9.5 & - & - & - & - \\
\hline Amarilla & 95.5 & - & 4.5 & 27.8 & 72.2 & - & - & - & - & - \\
\hline
\end{tabular}

${ }^{1} \mathrm{~B}=$ bought, $\mathrm{Bw}=$ borrowed, $\mathrm{T}=$ traded.

${ }^{2} \mathrm{O}=$ own, AOC=acquaintances from other communities, $\mathrm{N}=$ neighbors, $\mathrm{F}=$ family, $\mathrm{M}=$ market, $\mathrm{NGO}=\mathrm{id}$., $\mathrm{CS}=$ certified seller.

GE variety from a market). We analyzed farmers' potato marketing data from the survey to assess which markets might possibly contribute more to the chance of occurrence of GE/conventional potato seed mixtures resulting from contact between farmers and varieties in these markets (data not shown).

Markets in Lima receive the largest quantity of potatoes supplied by potato-selling farmers in Peru, altogether providing the market with a relatively high number of varieties. However, most farmers selling in Lima bring on average only a few (many times the same) potato varieties. On the other hand, markets such as the ones in Calca, Cusco, Hermelinda, and Urubamba (all in Cusco) supplied by many farmers (but fewer farmers than the markets in Lima) receive a higher average number of varieties per farmer. To better express the extent of contact between potato varieties and farmers at any given visiting moment at the market (relative to the other markets only), we introduce the Farmer Variety Contact Coefficient (Cfvc). Cfve is calculated as:

$$
\mathrm{Cfvc}=\frac{\mathrm{Nv} \times \mathrm{Nva}}{\mathrm{Nf}}
$$

Here, $\mathrm{Nv}$ is the number of different varieties sold in this market (observed), Nva is the total number of variety accessions sold by the farmers in this market during the course of the last season (e.g., if two varieties have been sold in a market, and variety $\mathrm{A}$ is sold by 10 farmers, and variety B by 20 farmers, then Nva for this particular market is 30), and $\mathrm{Nf}$ is the number of farmers selling their potatoes in this market (observed). Farmer Variety Contribution (Fvc, or average number of varieties per farmer) is calculated as Nva divided by Nf.

Cfve is lower in the Lima market, but from all markets in our assessment it is highest in Lamay, Chumpe, and Calca (all in Cusco), due to their higher average number of varieties per farmer, increasing the contact between farmers and varieties at any given visiting moment.

\section{Costs and benefits}

An important question is whether smallholder farmers in Peru would benefit from the deployment of an insectresistant (GE) variety. Our farmer survey confirms that many smallholder farmers use improved varieties, such as Canchan and Yungay (Tabs. 3 and 5). From the farmers with $0-0.49$ ha, $55.6 \%$ grows Canchan and $22.2 \%$ grows Yungay; for those with $0.5-0.99$ ha, $81.0 \%$ grows Canchan and $81.0 \%$ grows Yungay; for those with 12.99 ha, $58.4 \%$ grows Canchan and 52.6\% grows Yungay; and for those with 3-9.99 ha, 50.6\% grows Canchan and $46.3 \%$ grows Yungay.

The survey indicated that $97 \%$ of smallholder farmers would be willing to pay more for an insect-resistant potato variety, and that most smallholder farmers would be willing to support a price increase of S./ (Soles) ${ }^{3} 0.10$ to 0.30 per $\mathrm{kg}$ of seed tubers for an insect-resistant potato with a S./ 0.20 increase being the point of highest response (Fig. 1). The average price of a $\mathrm{kg}$ of seed tubers in Peru currently is about S./ 0.40 per $\mathrm{kg}$, so the indicated acceptable price increase of S./ 0.20 represents $50 \%$ of the current price. The most important reasons for the support of a higher price are the expectance of reduced yield losses and reduced investments in pesticides. These arguments were returned 19.8 and 16.8 times more often, respectively, than the third argument that favored the resistant potato because of reducing exposure to toxic

\footnotetext{
${ }^{3}$ The exchange rate at the time of the survey was 3.3 soles to 1 US dollar.
} 


\section{Number of respondents willing to pay extra price (soles/Kg seed)}

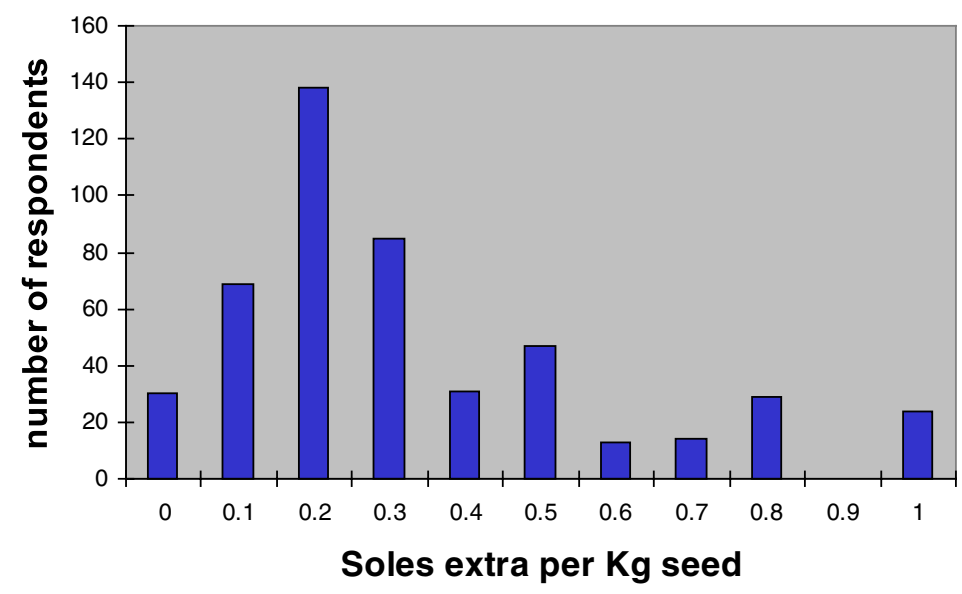

Figure 1. Number of respondents in farmer survey by amount more money in soles (Peruvian monetary unit) farmers would be willing to pay for $1 \mathrm{~kg}$ of seed tubers of an insect-resistant potato variety. Range is 0.0 to 2.0. Average is 0.345 . Exchange rate at the time of the research was 1 dollar to 3.3 soles.

Table 8. Percentages of farmers in different landholding size categories willing to pay price premium (soles), by height of price premium.

\begin{tabular}{lcrrrrrrr}
\hline \hline $\begin{array}{l}\text { Landholding } \\
\text { size (ha) } \downarrow\end{array}$ & $\begin{array}{c}\text { Price } \\
\text { Premium }\end{array}{ }^{1} \rightarrow$ & 0 soles & 0.1 soles & 0.2 soles & 0.3 soles & 0.4 soles & 0.5 soles & 0.6 soles \\
\hline $0-0.49$ & & $11.11 \%$ & $22.22 \%$ & $11.11 \%$ & $22.22 \%$ & $0.00 \%$ & $0.00 \%$ & $11.11 \%$ \\
$0.5-0.99$ & & $0.00 \%$ & $3.33 \%$ & $30.00 \%$ & $6.67 \%$ & $0.00 \%$ & $6.67 \%$ & $3.33 \%$ \\
$1-2.99$ & & $4.83 \%$ & $11.03 \%$ & $33.79 \%$ & $21.38 \%$ & $6.21 \%$ & $5.52 \%$ & $2.76 \%$ \\
$3-9.99$ & $5.79 \%$ & $16.22 \%$ & $22.78 \%$ & $16.60 \%$ & $6.95 \%$ & $11.97 \%$ & $2.32 \%$ \\
$10-50$ & & $7.55 \%$ & $15.09 \%$ & $35.85 \%$ & $13.21 \%$ & $3.77 \%$ & $11.32 \%$ & $0.00 \%$ \\
$>50$ & & $25.00 \%$ & $0.00 \%$ & $25.00 \%$ & $0.00 \%$ & $0.00 \%$ & $0.00 \%$ & $25.00 \%$ \\
\hline
\end{tabular}

${ }^{1}$ Standard deviation $=0.27$ and range $=0.0$ to 2.0 .

pesticides. The most commonly reported reasons for not being willing to pay extra were doubt about the effectiveness of resistance and lack of financial resources. The majority of smallholder farmers responded that they would not be able or willing to buy seed of the resistant variety every year.

When farmers are categorized by landholding size, the price increase of S./ 0.20 per $\mathrm{kg}$ is the most common response among most groups (Tab. 8). It was not the most common response for the groups with $0-0.49$ ha and $>50$ ha. These groups had the smallest number of farmers in the survey and thus the response distribution may be distorted.

It must be noted that farmers also suffer yield losses through insect damage, especially in storages, even while using pesticides. Field and storage damages were reported by farmers, and corresponding monetary losses were
Table 9. Average damages in soles per ha for potato tuber moth and Andean potato weevil in the field, and average damage in storages in soles. The value is the average of loss (soles/ha) \pm standard error of the mean.

\begin{tabular}{lcc}
\hline \hline & $\begin{array}{c}\text { Average field } \\
\text { losses (soles/ha) }\end{array}$ & $\begin{array}{c}\text { Average storage } \\
\text { losses (soles) }\end{array}$ \\
\hline Potato tuber moth & $403.3 \pm 74.9$ & $588.4 \pm 60.2$ \\
Andean potato weevil & $471.4 \pm 57.8$ & $216.3 \pm 53.8$ \\
\hline
\end{tabular}

calculated using an average price of 0.37 soles per $\mathrm{kg}$ of potatoes produced. The average losses due to potato tuber moth and Andean potato weevil in the field and in storage are shown in Table 9. These values are confident with a margin of error inferior to $12 \%$ (429 farmers out of the 500 , answered the survey for $85.8 \%$ of the response for the main problem). 
Farmers' current costs on pesticide use to control the most important insect pests averages S./286.43 per ha plus storage use as calculated from survey data (data not shown).

\section{DISCUSSION}

The impact on smallholder farmers of the diffusion of GE crops in developing countries is a central question of the International Agricultural Research Centers involved in agricultural biotechnology. These varieties need to be identifiable all along the production chain to implement specific crop management practices. The case studied here, insect resistant potatoes in Peru, presents two major crop management issues: reducing occurrence of pest resistance and of gene flow to non-GE varieties and related species. The former is related to the need to maintain a source of susceptible hosts at the proximity of the insectresistant variety to avoid pests becoming resistant. The desirability of gene flow in centers of origin and diversity of GE crops is still an unresolved issue.

The survey showed that production problems caused by Andean potato weevils and tuber moths were the second and third most important production constraints to farmers, respectively, right after late blight. Surprisingly, when lumped together, these insect problems collectively are as important as late blight. These results reveal the opportunity that host plant resistance to these pests could provide to farmers.

Contrary to the perception that smallholder farmers in Peru hardly cultivate commercial varieties, but instead mostly landraces, the survey showed that smallholder farmers are cultivating commercial varieties. Varieties such as Canchan, Yungay, Perricholi, and Unica are highly popular among all farmers (Tabs. 3 and 4). This is further exemplified in Tables 5 and 6, which show that these same commercial varieties are relatively popular with farmers of all sizes, even those with the smallest landholdings. This finding is extremely important, because any impact of commercialization of potato will also impact the fragile economy of smallholder farmers.

Considering whether an insect resistant variety should be new or similar to their existing varieties, farmers were divided almost equally between a conservative attitude current variety has a good market potential - and a progressive attitude - new variety may come with new attributes on top of insect resistance. This might indicate that whether new improved varieties should or shouldn't be different from existing varieties is not the most pertinent issue for farmers.
Farmers do not purchase seed yearly, but prefer to do so once every two to four years. They buy their seeds mainly through informal seed systems; the established national institution did not appear to play a significant role. For the variety Canchan, $91.7 \%$ of the seed tubers are bought (and the rest is traded or borrowed), but only 3.0\% of the bought tubers is bought from certified seed sellers. Thus it can then be estimated roughly that a maximum of $2.8 \%$ of all Canchan seed tubers used are bought from certified seed sellers. For Yungay this number is as low as $0.7 \%$, for Amarilis it is $1.4 \%$, and for Perricholi and Amarilla it is close to 0\%. The Peruvian formal seed system thus supplies only marginal amounts of certified seeds to farmers. This finding makes clear that variety diffusion through the private sector, often proposed for GE varieties, would be a very slow process for variety changes.

Almost $90 \%$ of the farmers felt that avoiding mixture of varieties was feasible if required. Nevertheless, the results summarized in Table 7 and the results on farmervariety contact imply that even when a GE potato variety is distributed through the formal seed system, it cannot be guaranteed that variety mixing will be avoided. The Cusco region forms an especially sensitive area, with high contact between farmers and varieties.

Not too surprising was farmers' rejection of the idea of maintaining a susceptible variety side-by side with the resistant variety (nearly 70\% felt they would not do so). Because sanctions for infringing crop management rules are unlikely to be effective, the resistance management system in place in developed countries needs to be reviewed. Even though the desirability of gene flow in centers of origin, or in the vicinity of landraces is still much debated, it is advisable to restrict gene flow in the particular case of insect-resistant potato varieties in the Andes. First, because under such limitation, the production of other potato varieties would play the role of refuge and provide susceptible populations of insects. A two-gene approach may also be advisable, to reduce the importance of the presence of refuges in the resistance management strategy. In a two-gene approach two different resistance genes are introduced into a crop, requiring the target pest to simultaneously develop resistance against both. Second, research on the occurrence of gene flow between cultivated and wild potato species in Peru concluded that due to ample possibility for cross-fertilizations, male sterile varieties should be used for planting GE potato crops in the Andean region (Celis et al., 2004).

Finally, the survey indicated that farmers have an entrepreneurial attitude towards a seed premium for insect 
resistance, with $97 \%$ of the farmers likely to accept a price increase. Surprisingly, even those farmers with smaller landholdings almost equally respond that a S./ 0.20 increase is acceptable, while we would have expected the farmers in the smaller size categories to respond more towards the smaller increases (Tab. 8). Assuming that S./ 0.10 (25\% of the current price of S./ 0.40 for conventional, improved potato seed tubers) per kg of seed tubers would be the extra price required to produce and distribute the insect-resistant GE potato, and taking an average of $1500 \mathrm{~kg}$ seed tubers required to sow one ha, this would mean roughly an extra cost of S./ 150 (\$ 45.5) per ha. Comparing this cost with the current pesticide use to control the most important insect pests, which averages S./ 286.4 (\$ 86.8) per ha plus storage use, a maximum net production cost reduction of S./ 136.4 (\$41.3) per ha could be realized if pesticide use were entirely eliminated with the use of a GE variety. Because potatoes suffer insect damage, even with pesticide application, it can be argued that an efficient insect resistant GE potato might be able to further increase the financial benefits for farmers by reducing these damages (Tab. 9). However, it must be noted that the pesticides used are applied for controlling both potato tuber moth and Andean potato weevil, and that an insect-resistant GE variety probably should combine resistance to both these insects (of orders Lepidoptera and Coleoptera) to become an effective and sustainable strategy. Moreover, the reduction in use of broad-range pesticides as a result planting insect-resistant potato, may result in increased importance of secondary insect pests. This could reduce the overall economic benefits from such an insect-resistant variety. More ecological studies should be carried out to investigate this balance.

Considering the importance of the informal seed system, we conclude that new models for rapid variety distribution are needed that embrace the involvement of the informal seed system and that integrate the service quality typical of the private sector. Given the results of this survey, the importance of the informal seed system, and the necessity of refuges, we suggest that the deployment of insect resistant GE potato varieties proceed only with selected commercial varieties that are sterile. Sterility, in vegetatively reproduced crops such as potato, allows control of gene flow whilst not hindering farmers to multiply their own planting material. The segregation between GE and non-GE varieties would rely on one or a number of unique characteristics of the GE variety that makes it easily recognizable and distinguishable. Such a variety-based segregation system would also be applicable to clonally propagated crops in other developing countries. Under a variety-based segregation system, appropriate policies may be developed to reduce labeling and monitoring costs, which might present distinct advantages in developing country settings.

\section{MATERIALS AND METHODS}

The prime method used for this research has been a farmer survey. The aim of the survey was to assess current potato cultivation constraints, current control methods and their associated costs, aspects of potato variety choice, and farmers' perception of the importance of advantages and disadvantages associated with the possible introduction of insect-resistant GE potato.

The survey was carried out in the Peruvian departments of Cajamarca and La Libertad in the northern highlands, Huánuco and Junín in the central Andes, and Cusco in the southern highlands. These departments were selected because of their importance as main potatoproducing areas in Peru. The interviews were done in the period of August-October 2003, during potato storage in the highlands. To estimate the size of the survey, we followed the method of Birnbaum and Sirken (1977) for completely random samples: $n=t_{\alpha}{ }^{2} P Q / d^{2}$, for infinite populations, where $t_{\alpha}$ is the standard normal deviate, $P$ and $Q$ are the proportion of responses, and $d$ is the margin of error. We used a risk $\alpha=2.5 \%$, the least favorable case of $P=0.5$, and a margin of error $d=5 \%$, to obtain the calculated sample size $n=2.24^{2} 0.25 / 0.05^{2} \cong 500$ individuals.

In total, 500 farms were surveyed, 100 in each department. In each department, four communities were selected and in each community, 25 farms were surveyed. An altitude range of 2000 to 3800 m.a.s.l. was kept as a parameter for community and farm selection. Within the altitude range, communities were selected based on ease of reach and already established contact with the interviewers, and to a minor extent on known prevalence of potato tuber moth. Farms were selected for complete surveying only if cultivating potato. No selectivity was used, however, concerning farm size, even though the majority of the farms in the selected areas fall under smallscale agriculture. Previous contact between interviewers and communities may have had a minor influence on the innovativeness of some of the interviewed farmers. Yet, the set up of our questionnaire and the type of questions asked have ruled out such bias as far as possible.

The survey consisted of 78 questions (single or composite), which were addressed by the interviewer using structured interviewing and standardized techniques. To minimize the risk of biased answers, the survey used the term 'new insect-resistant variety' instead of 'GE variety'. 
In each of the departments a different interviewer did 100 interviews, which were carried out at the farm.

\section{ACKNOWLEDGEMENTS}

This research was partly financed by the Dutch Directorate General for International Cooperation (DGIS). We would like to thank Omar Chaves, Jean-Paul Meza, Jose Otiniano, Guillermo Ramirez, and Wilber Villano for doing the survey interviews. Our gratitude also goes out to Dr. Oscar Ortíz, Dr. Cristina Fonseca and Dr. Verónica Cañedo for their extensive contribution to the development and the coordination of the survey. Dr. Oscar Ortíz and Dr. Paul Stapleton are also thanked for their critical review and editing of earlier versions of this paper.

Received May 4, 2005; accepted January 17, 2006.

\section{REFERENCES}

Betz FS, Hammond BG, Fuchs RL (2000) Safety and advantages of Bacillus thuringiensis-protected plants to control insect pests. Regul. Toxicol. Pharm. 32: 156-173

Birnbaum ZW, Sirken MG (1977) Effects of nonresponse. In Cochran WG, Sampling Techniques, John Wiley \& Sons, Inc., p 359

Celis C, Scurrah M, Cowgill S, Chumbiauca S, Green J, Franco J, Main G, Kiezebrink D, Visser RGF, Atkinson HJ (2004) Environmental biosafety and transgenic potato in a centre of diversity for this crop. Nature 432: 222-225

Cohen JI, Paarlberg R (2002) Explaining restricted approval and availability of GM crops in developing countries. AgBiotechNet, Vol. 4, ABN 097

Cole DC, Carpio F, Julian JA, Leon N (1998) Health impacts of pesticide use in Carchi farm populations. In Crissman CC, Antle JM, Capalbo SM, eds, Economic, environmental, and health tradeoffs in agriculture: pesticides and the sustainability of Andean potato production, Kluwer Academic Publishers, Massachusetts, USA, pp 209-230

Falconi CA (1996) Funding agricultural biotechnology in Peru: A profitable investment. In Turning priorities into feasible programs: Proc. of a policy seminar on agricultural biotechnology for Latin America, Peru, 6-10 October, 1996, pp 114-122

Ghislain M, Bonierbale M, Nelson R (1999) Gene technology for potato in developing countries. In Hohn T, Leisinger KM, eds, Biotechnology of food crops in developing countries, Springer-Verlag, Vienna, pp 105-141

Ghislain M, Lagnaoui A, Walker T (2003) Fulfilling the promise of $B t$ potato in developing countries. J. New Seeds (USA) 5: 93-113

Huamán Z (1998) Collection, maintenance and evaluation of potato genetic resources. Plant Var. Seeds 11: 29-38

Kough J (2003) The safety of Bacillus thuringiensis for human consumption. J. New Seeds 5: 1-10

Lapan HE, Moschini G (2004) Innovation and trade with endogenous market failure: the case of genetically modified products. Am. J. Agr. Econ. 86: 634-648

McLean MA, Frederick RJ, Traynor PL, Cohen JI (2002) A conceptual framework for implementing biosafety: Linking policy, capacity, and regulation. ISNAR Briefing Paper 47

Pray CE, Huang J, Ruifa H, Rozelle Sc (2002) Five years of Bt cotton in China - the benefits continue. Plant J. 31: 423430

Qaim M, Zilberman D (2003) Yield effects of genetically modified crops in developing countries. Science 299: 900902

Salas AR, Spooner DM, Huamán Z, Torres Maita RV, Hoekstra R, Schüler K, Hijmans RJ (2001) Taxonomy and new collections of wild potato species in central and southern Peru in 1999. Am. J. Potato Res. 78: 197-207

Shelton AM, Zhao J-Z, Roush RT (2002) Economic, ecological, food safety, and social consequences of the deployment of transgenic plants. Annu. Rev. Entomol. 467: 845-881

Spooner DM, Salas AR, Huamán Z, Hijmans, RJ (1999) Wild potato collecting expedition to southern Peru (Departments of Apurímac, Arequipa, Cusco, Moquegua, Puno, Tacna) 1998: Taxonomy and genetic resources. Am. J. Potato Res. 76: 103-119

Thiele G (1998) Informal potato seed systems in the Andes: Why are they important and what should we do with them? World Dev. 27: 83-99

Weiss R (2000) EPA restricts gene-altered corn in response to concerns. Farmers must plant conventional 'refuges' to reduce threat of ecological damage. Press rel., Washington Post, Jan. 16,2000 